\title{
Vulnerability of Construction Workers During COVID-19: Tracking Welfare Responses and Challenges
}

\section{Ajit Jha ${ }^{1}$}

Accepted: 24 September 2021 / Published online: 1 November 2021

(c) The Author(s), under exclusive licence to Indian Society of Labour Economics 2021

\begin{abstract}
This paper takes stock of the cash assistance provided by the government to construction workers during the COVID-19 pandemic. As the role of the state construction welfare board has been crucial, some existing issues related to boards and challenges emerged during the crisis have also been discussed. Results show that cash benefit through direct benefit transfer has partially helped workers to overcome their financial distress, but $65 \%$ workers did not receive any benefit due to various issues related to registration and seeding of bank accounts with Aadhar. Sluggish process of registration has been a major issue which is being addressed by different mechanisms, but results would be known later. Proper cess collection and its utilisation is still an important issue as $61 \%$ of the cess collected in 2019 was not utilised. Even during the crisis, $15 \%$ cess was used at most in direct benefit transfer and in-kind (food distribution) support. Majority of the states are running a number of welfare schemes, but the coverage is poor despite proper guidelines set under the Model Welfare Framework of the Ministry of Labour and Employment. The objectives of Mission Mode Projects are appreciable, but the outcomes are not known even after the completion of deadlines. Above all, the emerging issues of maintaining health and hygiene at worksite and living place and getting vaccinated are major challenges for the sustainability of the construction sector. Hence, a collective effort of the government, employers, and workers' organisations is the need of the hour.
\end{abstract}

Keywords COVID-19 · Construction · Migration · Workers · Direct benefit transfer

\section{Introduction}

The impact of COVID-19 on labour market is deep and much severe than the previous economic crises (Breman, 2020; Jha and Kumar, 2020). Globally, 81\% workers borne the brunt of the pandemic, 225 million jobs were been lost, and the global

Ajit Jha

ajitjha@isid.org.in

1 Institute for Studies in Industrial Development (ISID), Vasant Kunj, New Delhi 110070, India 
labour income has declined by $8.3 \%$ in the year 2020 (ILO, 2021a). The destruction in jobs and labour income has disproportionally affected the young, women, unprotected, disadvantaged, and migrant workers across the world (ILO 2020a, 2021a). In many economies, the young labourers who were already battling (high) unemployment before the pandemic are now vulnerable due to the falling labour demand during the crisis. Sectors where women were fairly represented have been hit hard; unprotected workers are disproportionally affected because of lack of social security benefits such as provision of paid or sick leave. The plight of the poor and vulnerable migrant workers has become visible in this period. They face multiple challenges including not getting their due wages from their employers, loss of employment, inability to access new jobs, and inability to pay accommodation rent (ILO, 2020a, 2021a; Breman, 2020; Srivastava, 2021; Addison et al., 2020; Rajan et al., 2020; Walter, 2020).

The crisis in India came in the backdrop of the pre-existing labour market fragilities reflected in higher informality, poor social protection, and high unemployment rate (Srivastava, 2020a, 2020b, 2020c; Kapoor, 2020). According to the Periodic Labour Force Survey (PLFS) 2018-2019 data, around 90\% of the total workforce in India is informal, working without a proper job contract and social security. These workers living in the countryside and in slums in mega-cities were already working in poor conditions and living in filthy environment (Breman, 2020), and the disruption in economic activity and mobility restriction during lockdowns further increased their vulnerability. The impact was felt most by the migrant workers (seasonal and circular) working in the informal sector (Srivastava et al., 2020; Rajan et al., 2020; Srivastava, 2020a, 2020b, 2020c, 2021). According to an estimate, in the urban labour market $51 \%$ workers are migrants and a significant proportion (111 million in 2017-2018) comprises circular migrant workers (Srivastava, 2020a, 2020 b, 2020c). Due to social fragmentation, unstable accommodation, poor entitlements, and lack of organisational and political voice, they have a weak foothold in the urban labour market (Srivastava, 2020a, 2020b, 2020c; Breman, 2020; and APU, 2021). Even during the second wave in mid-April and May 2021, lakhs of circular migrants returned home in anticipation of the spread of the virus and due to lockdowns in major part of the country. According to a report by the Ministry of Labour and Employment (MoLE), around 1.3 million workers left Delhi during mid-April and May 2021 (Hindustan Times, July 2, 2021). A cessation of economic activity has had severe impact on employment and income. Estimation based on Centre for Monitoring Indian Economy (CMIE) CPHS data on employment showed that more than 100 million people lost jobs during first wave in March-April 2020. Though jobs recovered sharply after unlocking of economic activities, overall annual employment in 2020-2021 was below the pre-COVID level. There is an estimate that mobility restriction led to the $17 \%$ fall in monthly income during the first wave of COVID-19 (APU, 2021). Surveys (Kesar et al., 2020; Dalberg, 2020) conducted during the first wave of COVID-19 and anecdotal evidence collected also suggest that there would have been significant income losses especially to informal workers (The Hindu, 2021).

The crisis affected every section and sector of the economy albeit at different levels and made the role of the government paramount. Protection of health and 
economic support both at the demand and the supply side of the economy were the immediate goals suggested to arrest the fallout of the crisis (ILO, 2020a). Governments across the globe adopted containment and economic support measures such as additional spending, temporary tax cut, cash and in-kind support, unemployment benefits, wage subsidies, and other kinds of liquidity support measures.

The central government in India adopted a graded pre-emptive and pro-active strategy consisting of containment measures, fiscal support, and financial and structural reforms to combat COVID-19. The government introduced phase-wise demand stimulus with prior focus on measures to provide a cushion for the poor and vulnerable section of the society and to the small business sectors. Some of these measures included food grain distribution programme, direct cash transfer to individuals, and cash support to registered construction workers (GOI, 2021). On March 26, 2020, the Ministry of Finance announced a Rs. 1.7 trillion packages under Pradhan Mantri Garib Kalyan Yojana (PMGKY) covering all of the above welfare measures for targeted groups (PIB, 2020a). Later a special economic package called Aatmanirbhar Bharat Package was launched as a part of the national economic response to COVID-19 pandemic.

An evaluation of PMGKY based on large-scale CMIE survey of households shows that between May and August 2020, more than $87 \%$ of the beneficiaries reported receiving at least one benefit-food. Across the country, nearly $40 \%$ of the households received cash transfers (Bhattacharya and Roy, 2021). However, objections have been raised regarding the way lockdown imposed and PMGKY package was announced and implemented. The support package was found to be inadequate and poorly targeted (Breman, 2020; Srivastava, 2020a, 2020b, 2020c; Rajan et al., 2020 and Jha \& Kumar, 2021).

In the above context of informality, migrant crisis, and welfare responses of the government, the present paper tries to elucidate the impact of the crisis on the construction workers in India. It is important to note that informality is a norm in the construction sector as both enterprises and workers are highly informal (Wells, 2007). Studies (Mehrotra and Giri, 2019; Kapoor, 2019; and, Srivastava, 2020a, $2020 b, 2020$ c) have shown that there is a large presence of micro- and informal enterprises $(99.1 \%)$, informal workers $(92.5 \%)$, and circular migrant workers $(26.4$ million) in India's construction sector. During the COVID-19 crisis, their financial and occupational conditions became highly deplorable. Migrant construction workers faced significant economic hardship due to loss of jobs and unhygienic and improper living conditions in which maintaining social distancing may not be possible (ILO, 2021b). A risk analysis of different sectors affected from COVID19 in India also showed that along with services, construction has been the worst affected sector (GOI, 2021). A drastic decline in construction gross value added (GVA) (-49.5\%) was noticed in the first quarter (April-June) of 2020-2021. In fact, the contraction in GVA was highest among all sectors. Compared to the percentage change in GVA in 2019-2020 (1.0\%), the change in construction GVA in 2020-2021 is reported to be (-)8.6\% (MOSPI, 2021). The decline in employment was also very sharp. As per CMIE data on employment, the year-over-year (YOY) change in construction employment was (-)55.4\% in the first quarter of 2020-2021. In absolute terms, 34 million workers lost their jobs in the first quarter. Overall, 
around 3 million construction workers lost their jobs in 2020-2021 as compared to 2019-2020.

On the other side, some intervention measures like the gradual easing of the lockdown and mobility restrictions have helped the sector to turn upward and the response of the government to provide direct cash assistance and other in-kind support to workers has been noticeable, but a detailed outcome is a matter of evaluation. Further, occupational safety, health and hygiene, proper accommodation, social security benefits, and infection prevention measures have become major issues for construction workers because of the physical intensive nature of the industry (Lingard et al., 2021).

Given this background, the study finds it appropriate to discuss the nature of employment and working conditions of construction workers and the response of the government both at union and the state levels to mitigate their vulnerabilities. Existing issues and future challenges in the given regulatory framework for construction workers have also been discussed. The paper has two objectives. One, to document and analyse the way the construction workers received assistance by the union and state governments to compensate for their loss of earnings due to the lockdowns during the first and second waves of COVID-19. And two, to identify issues related to construction workers that already existed and those that emerged during the crisis and how they can be dealt with.

The structure of the paper is as follows. Following the introductory section, the data and methods used in the study are covered in Section 2. Section 3 discusses the nature of employment and working conditions in the construction industry. The policy response of the central and state governments is analysed in Section 4 and in Section 5, and exiting issues and future challenges are discussed. Section 6 concludes with a discussion.

\section{Data and Methods}

A major part of the analysis is based on secondary data. Information relating to the total number of workers, employment status, job contract, and social security is based on the estimation of unit-level data of Employment and Unemployment Round (2011-2012) of NSSO and PLFS 2018-2019. State-wise data on registration of workers, collection, and spending of cess have been compiled from the unstarred and starred questions asked of MoLE and other concerned ministries during Rajya Sabha and Lok Sabha sessions. Though the data given by MoLE and other ministries on registration of workers and cess collection are not error free, they are the only reliable source to get state-level information on such variables. The GVA data at 2011-2012 prices at all India level and state-wise have been taken from the Ministry of Statistics and Implementation Programme (MOSPI).

Generally, the estimation of number of workers is done for the age group 15-59. But in this paper, estimation of workers is done for the age group of 18-60 years to bring them at par with the way registered workers are counted. Under Section-12 of Building and Other Construction Workers (Regulations of Employment and Conditions of Services) Act 1996 (hereinafter BOCW Act), a worker is eligible for 
registration if he/she has completed 18 years of age but has not completed 60 years of age. Estimation of informal workers is based on two criteria: (a) job contract and (b) number of workers present in an enterprise.

To substantiate the analysis based on secondary data, case studies of some workers doing construction and other works have also been reported.

\section{Nature of Workforce in the Construction Industry}

Heterogeneity is an inherent characteristic of the construction industry because of the discrete nature of its products. The industry is sensitive to economic cycles, and informality is present in every aspect of it (Loop, 1996; Wells, 2007; and, ILO, 2021b). Subcontracting of both capital and labour is a practice, and the chain increases with the nature and scale of operation (Srivastava and Jha, 2016; Jha, 2017). Labour is an important factor of production, and the sector provides a significant source of direct employment to less educated or low-skilled and migrant workers having origin in rural areas (Loop, 1996). But the nature of employment is mostly transitory, and the nature of the workforce is highly informal. The industry is highly dependent on migrant workers as they are mobile in nature. They are also flexible and expandable in terms of economic delivery (Buckley et al., 2016). It has also been observed that the proportion of migrant workers varies with the scale and location of the construction activity, and they are mostly hired through labour contractors (Loop, 1996; Srivastava and Jha, 2016; and, Jha, 2017). In fact, migrant labour has gained centrality in the construction sector, both because of the spatial disconnect between labour supply and demand, and because of the labour recruitment system (Srivastava, 2018). Long-distance migrants are preferred as they can be hired on relatively lower wages (Roy et al., 2017; and, Loop, 1996).

A true resemblance of these characteristics can be observed in Indian construction industry. Construction in India is a major labour-intensive sector as it contributes over $12 \%$ share in total employment. As compared to $89.6 \%$ informal workers in India in 2018-2019, in construction, 92.7\% workers were informal. ${ }^{1}$ The share of wage workers $(88.8 \%)$ and casual workers $(83 \%)$ was also very high (Fig. 1).

Around $97 \%$ workers had no formal contract with their employers (Fig. 2). There is also not much difference between formal and informal workers in terms of receiving social security benefits. Only $2.5 \%$ (formal and informal) workers received some kinds of social security benefits (Table 1). Both primary and secondary data analysis shows that over $90 \%$ workers in construction had received secondary education or below and more than $80 \%$ had no formal training. Although low level of education and informal skill acquisition is common in the construction industry, it makes them highly vulnerable to layoffs (Jha, 2017; and, Kapoor, 2020).

Migration has been a key source of labour employment in the construction sector in India. Based on Census 2001 data, out of 14.6 million construction workers, 4.9 million were migrants and $10 \%$ of non-agricultural internal migrants were employed

\footnotetext{
1 Globally, 75.7 percent workers are in informal employment (ILO, 2020b).
} 


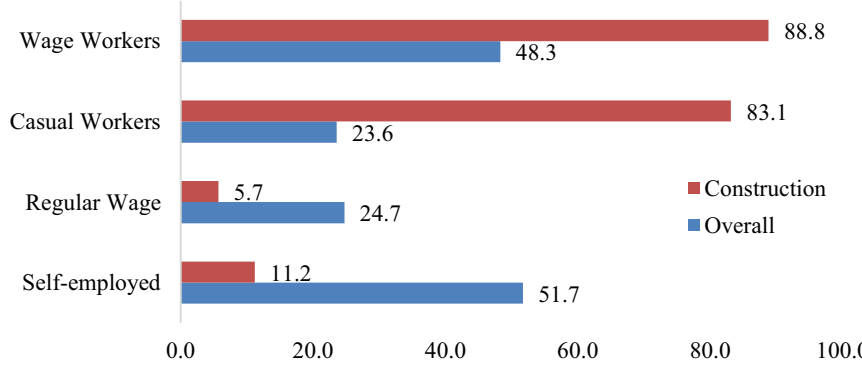

Source: Estimation Based on PLFS, 2018-19

Fig. 1 Pre-COVID-19 labour market structure (in per cent). Source: Estimation based on PLFS, 20182019

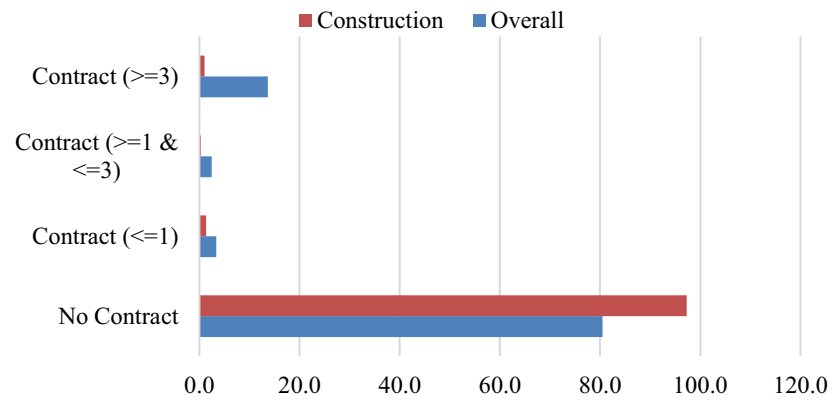

Source: Estimation Based on PLFS, 2018-19

Fig. 2 Availability of written job contracts (in years). Source: Estimation based on PLFS, 2018-2019

Table 1 Status of social security benefits in 2018-2019

\begin{tabular}{lccccc}
\hline Social security & All sectors & & & \multicolumn{2}{l}{ Construction } \\
\cline { 5 - 6 } & Total workers & Informal workers & & Total workers & Informal workers \\
\hline Any benefits & 26.5 & 12.1 & 2.5 & 1.4 \\
No benefits & 65.9 & 78.9 & & 87.5 & 88.1 \\
Not known & 7.6 & 9.1 & & 10.0 & 10.4 \\
Total & 100.0 & 100.0 & & 100.0 & 100.0 \\
\hline
\end{tabular}

Source: Estimation based on PLFS, 2018-2019

in the construction sector (Roy et al., 2017). But the major issue with Census data is that it does not capture the short-term seasonal and circular migrants whose numbers are very significant in the construction sector (Srivastava, 2014, 2018). Also, 
sector-specific migration data collected in Census 2011 are not yet released. Construction is the largest employer of interstate short-term migrant workers. Around $36 \%$ of all short-term migrants (circular) are engaged in construction activity (Srivastava, 2018). The total number of circular migrants in construction activity increased to 26.4 million in 2017-2018 from 24.9 million in 2011-2012 (Srivastava, 2020a, 2020b, 2020c). A few empirical studies (Srivastava and Jha, 2016; Jha, 2017) based on the primary survey of construction workers conducted in 2012-2013 in Delhi NCR also show that more than $90 \%$ of the workers doing work on large construction sites were seasonal and circular migrants, and majority of them hail from Uttar Pradesh, Bihar, and West Bengal. They come from rural areas through labour suppliers on a fixed wage rate time period and work for two to six months in a spell. The circular nature of migration can also be understood from the case history of a construction worker who is presently working in a building construction project in Vasant Kunj area of Delhi.

Hanshul $^{2}$ is a 35-year-old manual worker who hails from Malda district of West Bengal. He is landless and there are six members in his family. To sustain his family, he and his wife have to work as farm labour and sometimes as non-farm labour. For the past five years, he is working for a munshi (middleman) who belongs to his native district Malda. Twenty other people from his village are also working with him as manual workers. According to Hanshul, he comes to Delhi twice in a year for work. Each time he stays for two months and then goes back to his native place where he remains for the next eight months of the year working for either local farmers or in public works... (Primary Survey by Author, Vasant Kunj, New Delhi, June 29, 2021).

Some of the representative surveys of workers conducted during the COVID-19 crisis have documented the miseries faced by migrant workers due to loss of jobs, non-payment of wages, shutting down of temporary accommodation, and denial of journey allowances. An important survey conducted by Self Employed Women's Association (SEWA) of 2,668 construction workers, street vendors, and domestic workers in five cities (Delhi, Lucknow, Ranchi, Ahmadabad, and Trivandrum) found a huge drop in household income during the pandemic (APU, 2021). According to this survey, $78 \%$ construction workers reported zero income due to the lockdown. Estimation of wages from PLFS 2018-2019 data and comparing it with the lockdown period indicates that these workers suffered huge wage loss. As per the PLFS 2018-2019 data, on an average, a casual worker earned Rs. 371 nominal wage per day in urban areas, whereas a regular worker earned Rs. 566 per day. As the first lockdown was imposed for 21 days, it can be estimated that the loss to casual worker and regular worker was Rs. 8000 and Rs. 12,000, respectively (Table 2).

The miseries that the migrant construction workers faced can also be gauged from the case history of one of the respondents:

\footnotetext{
${ }^{2}$ The name is only indicative. The actual name of the respondent has been changed to maintain anonymity.
} 
Table 2 Wage and earnings of workers in construction industry (in Rs.)

\begin{tabular}{llll}
\hline Wage & Male & Female & Total \\
\hline Regular monthly & & & \\
$\quad$ Rural & 11,876 & 17,848 & 11,983 \\
Urban & 17,356 & 15,910 & 17,271 \\
Regular daily & & & \\
$\quad$ Rural & 389 & 585 & 393 \\
$\quad$ Urban & 569 & 522 & 566 \\
Casual daily & & & \\
$\quad$ Rural & 316 & 196 & 303 \\
$\quad$ Urban & 380 & 279 & 371 \\
\hline
\end{tabular}

Source: Estimation based on unit level PLFS data, 2018-2019

Kuldeep Manjhi (45-year-old), who hails from Jamui district of Bihar, works as a mason at construction sites. He has been working in Delhi and Noida for the past 15 years and moves from one construction site to another, sometimes with the same labour contractor and other times through an informal contact. On an average, he earns Rs. 15,000 to Rs. 20,000 per month. During the first wave of COVID-19 crisis, he was working at a construction site in Noida. After the lockdown was imposed, he and some other workers of his village decided to stay at the construction site. After 10-15 days of lockdown, they had barely money left to sustain themselves. Even the labour contractor was also staying with them had no money left to stay longer. Therefore, they decided to leave the site and return to their native villages. After three days of cycling and hardship, they reached home. He stayed there for three months and did some work to manage his livelihood but finally returned to Delhi in the month of September 2020 mainly because he had taken an advance from the contractor with whom he was working (Primary Survey by Author, Masoodpur Village, Vasant Kunj, New Delhi, June 30, 2021).

\section{Assistance to Construction Workers During COVID-19}

To help mitigate the crisis, two broad measures were implemented worldwide: supporting jobs and incomes, and protecting workers at construction sites. Many countries implemented short-time work schemes and provided wage subsidies and income support to workers. Though these measures were not specific only to construction workers, due to prevalence of informality in the construction sector it was assumed that these policies would also impact construction workers (ILO, 2021b). It was also expected that as major stakeholders, the government, employers, and workers' union will provide all possible help to workers. This study, however, focuses only on government support to construction workers due to the unavailability of reliable information for other stakeholders. 
The Indian government implemented a cash transfer programme along with inkind support to provide a kind of subsistence allowance and short-term relief to construction workers during the crisis. Some states such as Bihar and Maharashtra also provided in-kind support to construction workers and bore the (special) rail and bus fares of migrant workers returning to native places. To provide cash assistance to construction workers, MoLE under Section-60 of BOCW Act 1996 advised all states and CWBs to frame a scheme under Section 22 (1) (h) of the Act for transfer of funds in the accounts of construction workers through DBT mode from the cess fund collected by CWBs (PIB, 2020a). According to MoLE advisory, about Rs. 520 billion was available as cess fund, which may be given to 35 million registered construction workers. ${ }^{3}$

In response, most the states and union territories through CWBs provided cash assistance to construction workers whose registrations were renewed, and bank accounts were seeded with Aadhar. This, however, left out a significant number of those who were not registered. So far, the government claims to have provided Rs. 56.18 billion cash assistance through DBT to 18.3 million workers during the first wave and Rs. 17.9 billion disbursed to 12 million workers in the second wave in April-May 2021 (Lok Sabha, 2021a, 2020; and, The Hindu, 2021).

However, analysis of the available statistics shows major discrepancies in data reporting, state-wise variation, and inadequate cash distribution. It is found that only around $52 \%$ of the total registered (34\% of total estimated) workers have received cash assistance-either one-time or on periodic basis (Table 3), which also implies that a large number of workers could not get the benefit due to non-availability of bank details of registered workers linked to Aadhar. Few states had not disbursed even a single penny due to the absence of such record (MoLE, 2020).

With respect to PMGKY, the first progress report (April 2020) shows that 21.7 million construction workers have been benefited through DBT (PIB, 2020c). A total of Rs. 30.7 billion cess funds were used for this purpose. The second progress report (June 2020) shows that 23 million workers have benefitted with the use of Rs. 43.1 billion cess funds (PIB, 2020d).

\footnotetext{
${ }_{3}^{3}$ Two issues are important to raise here. One, there are some other national- and state-level schemes and cash assistance programmes for which construction workers are also eligible and it is found that during the COVID-19 crisis, a significant proportion of construction workers have received assistance, but in the present study those schemes are not evaluated. The paper strictly deals with the assistance accrued from CWBs.

Second, the claims of DBT made by the respective CWBs can only be testified by the field survey of construction workers. Some surveys such as Standard Workers Action Network (SWAN), 2020, and Dalberg, 2020 conducted during first wave of COVID-19 provide an assessment of the situation of migrant construction workers and welfare measures of the government. These surveys, however, have not captured DBT through CWBs. Reports published by SWAN in April and May 2020 state that most of the workers contacted them during the crisis were migrant construction workers. According to SWAN Report of May 2020, more than 90 percent of total workers (16,863 stranded workers) did not receive any cash transfer from the central and state governments. Dalberg (2020) conducted a large multi-round survey of 47,000 low-income households in 15 states between April 5 and June 3, 2020. From the report, it is found that a significant proportion of the households in the survey were construction workers and a significant proportion of them have received entitlement schemes that offered top-ups or advance payments.
} 


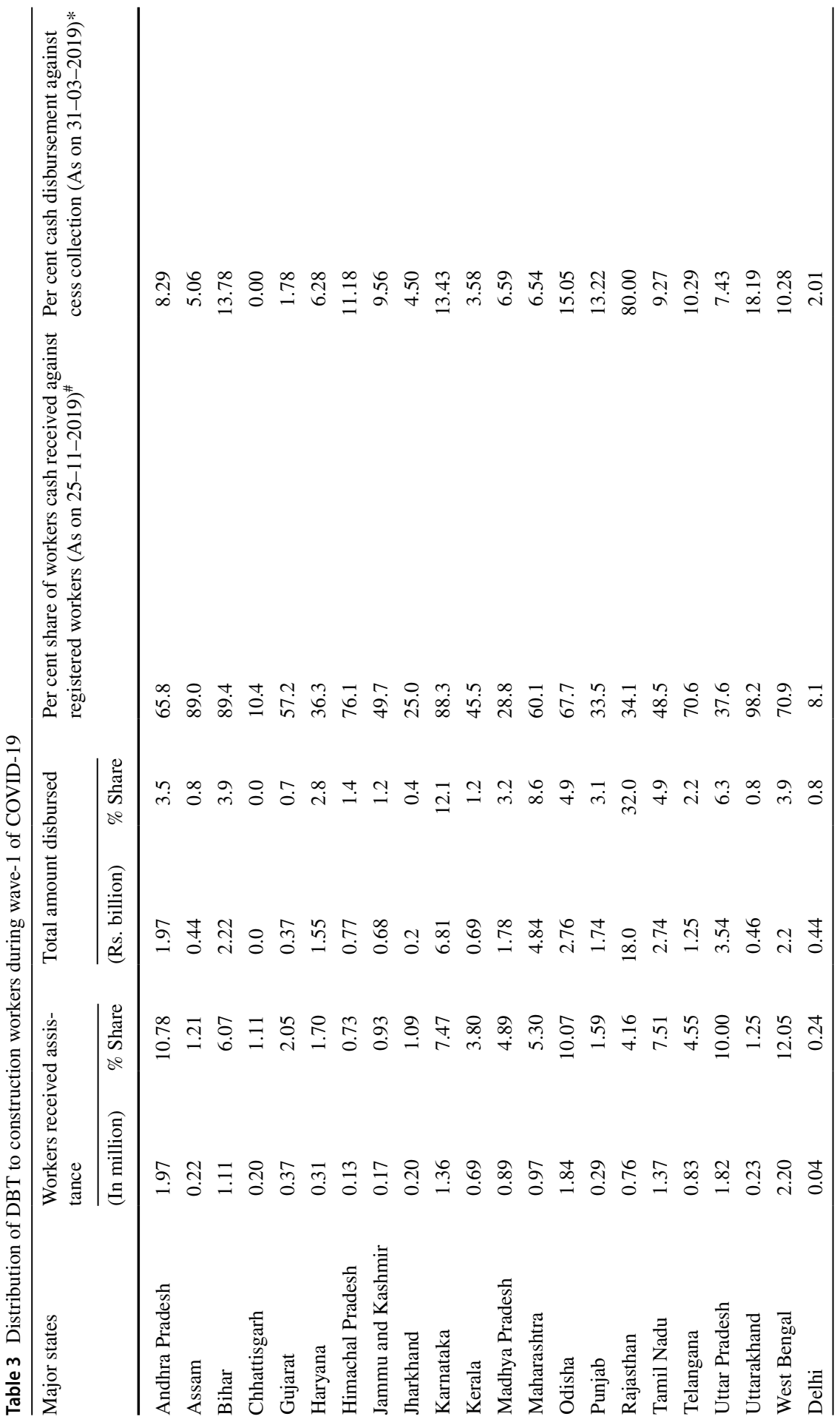




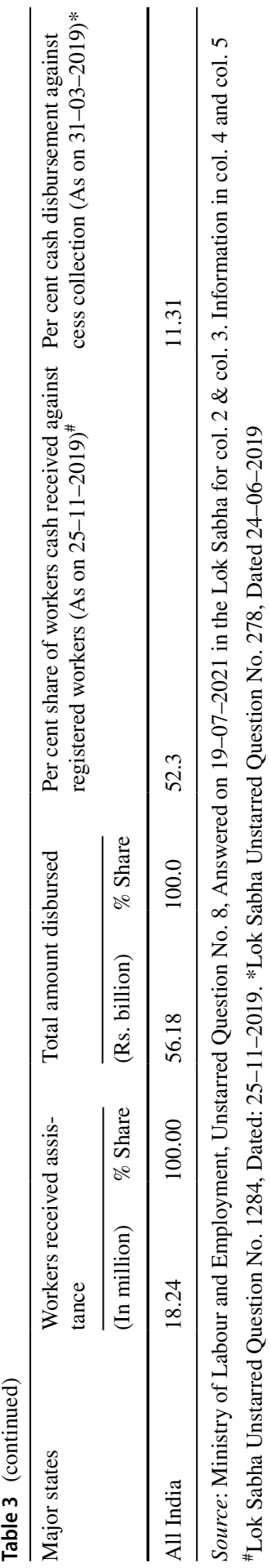


Contrary to the above reports, the Ministry of Finance in its press release dated September 8, 2020, revealed that 18.2 million construction workers were given cash assistance through DBT and a total of Rs. 49.87 billion had been spent (PIB, 2020e). In a reply submitted by the MoLE in Lok Sabha on September 19, 2020, the Ministry mentioned that Rs. 49.8 billion have been spent in providing cash through DBT and in-kind support to 18.2 million workers by the CWBs (Lok Sabha, 2020). The anomaly with respect to the number of workers raises doubts about the actual benefits to workers.

According to MoLE, the disbursement of Rs. 49.8 billion was in the form of DBT (Rs. 37.9 billion) and various types of in-kind support (Rs. 11.9 billion). It was also told that Bihar, Jharkhand, and Chhattisgarh had not been able to provide direct cash assistance (Rajya Sabha, 2020). However, in its current reply on July 19, 2021, in the Lok Sabha, the Ministry stated that Bihar has given Rs. 2.22 billion to 1.1 million construction workers during the first wave of the crisis (Lok Sabha, 2021a, 2020b). Bihar government also claimed to have provided direct cash assistance of Rs. 1000 to all natives of Bihar stranded in other parts of the country (Government of Bihar, 2021). The ministry also mentioned that two lakh construction workers each in Jharkhand and Chhattisgarh have received cash or in-kind benefits (Table 3). The major discrepancy is related to cash distribution in Rajasthan. Earlier, in the reply by MoLE (September 19, 2020), it was shown that 2.23 million construction workers had received cash assistance through DBT and a total of Rs. 5.58 billion was spent (Lok Sabha, 2020). The current reply, however, shows that only 7.6 lakh construction workers in Rajasthan have received direct cash assistance, while the total cess fund distributed is around Rs. 18 billion (Table 3). The lack of coordination in information sharing between the states and the centre and among the ministries has brought such misinformation, which must have come in the way of providing effective support to construction workers.

At the state level, there are huge variations in terms of the total number of workers who received the cash assistance and the total amount distributed against the available cess fund (available as in 2019). In Assam, Bihar, Himachal Pradesh, Karnataka, Andhra Pradesh, Maharashtra, Odisha, Telangana, Uttarakhand, and Gujarat, more than $50 \%$ of the total registered workers received cash assistance. In Delhi, where migrant construction workers faced a huge crisis, cash assistance was provided to only $8 \%$ of the registered workers. Overall, $52.3 \%$ registered workers received cash through DBT. The disbursement of cash against the available cess fund as in 2019 shows that Rajasthan distributed $80 \%$ of the cess fund through DBT to 7.6 lakh construction workers, which is many times higher than the national average of $11.3 \%$. States like Uttarakhand (18\%), Bihar (13.7\%), Odisha (15\%), Karnataka (13.4\%), Punjab (13.2\%), Himachal Pradesh (11\%), Telangana (10\%), and West Bengal (10\%) spent in the range of $10-15 \%$ of their available amount of cess funds. Total distribution of available cess fund was two per cent or lower in Delhi and Gujarat. Kerala (7.0\%), Tamil Nadu (13.1\%), and Uttar Pradesh (11.7\%) had significantly higher share of construction GVA in national GVA; however, these states together spent around $20 \%$ of the total cess fund. Kerala spent only $3.6 \%$ of cess fund, whereas Tamil Nadu and Uttar Pradesh 


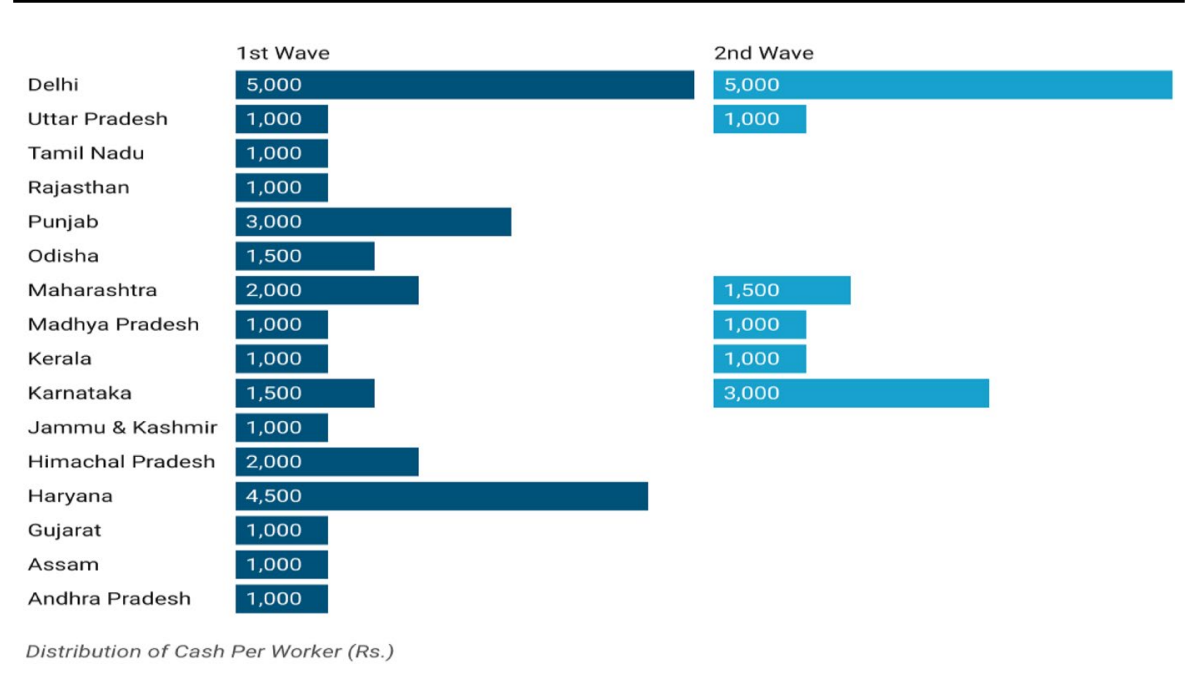

Fig. 3 State-wise distribution of cash through DBT during the first and second wave of COVID-19. Source: Compiled from COVID-19 labour market measures (India), ILO; CSE Azim Premji University and 25th parliamentary standing committee report on labour 2021

spent $9.2 \%$ and $7.4 \%$, respectively. Many of these states also have a higher share in the total cess collection. (Details are discussed in Section 5.)

In general, majority of the states gave only one-time cash assistance of Rs. 1000 during the first wave of COVID-19. States like Delhi, Haryana, Goa, and Punjab gave per worker assistance between Rs. 1000 and Rs 5000. States like Haryana and Himachal Pradesh provided cash assistance on per month basis (Fig. 3).

The impact of the second wave has undisputedly been severe in terms of health crisis. But the lockdown restrictions were not stringent during the second wave of COVID-19; hence, the impact on construction workers was also partial. Moreover, there was no interstate mobility restriction, provided the RT-PCR (real-time reverse transcription-polymerase chain reaction) report of the traveller was negative. Despite this, it was reported that lakhs of migrant workers left for their homes. To deal with this crisis and also to meet the demand by the workers' union to provide subsistence allowance to workers during the closing down of construction activities, Karnataka, Kerala, Madhya Pradesh, Punjab, Uttar Pradesh, and Delhi have given cash assistance through DBT to registered workers (Table 4). Overall, $4.5 \%$ of the fund available in 2021 was distributed among 35.6\% workers. Governments of Delhi and Karnataka have claimed to have given Rs. 5000 per worker cash assistance, while Uttar Pradesh, Madhya Pradesh, and Kerala gave Rs. 1000 per worker assistance during the second wave (see Fig. 3).

However, it is not specified whether migrant workers also benefited from the cash transfer as in many states proof of domicile is required for registration. Although the BOCW Act 1996 is the single largest provision for construction workers, many states have not accommodated these migrants in the registration and welfare provisions. In some states, rules are also not clear (Desai, 2017; Roy et al., 2017; and, Srivastava et al., 2020). Though Model Welfare Framework (2018) and Mission 


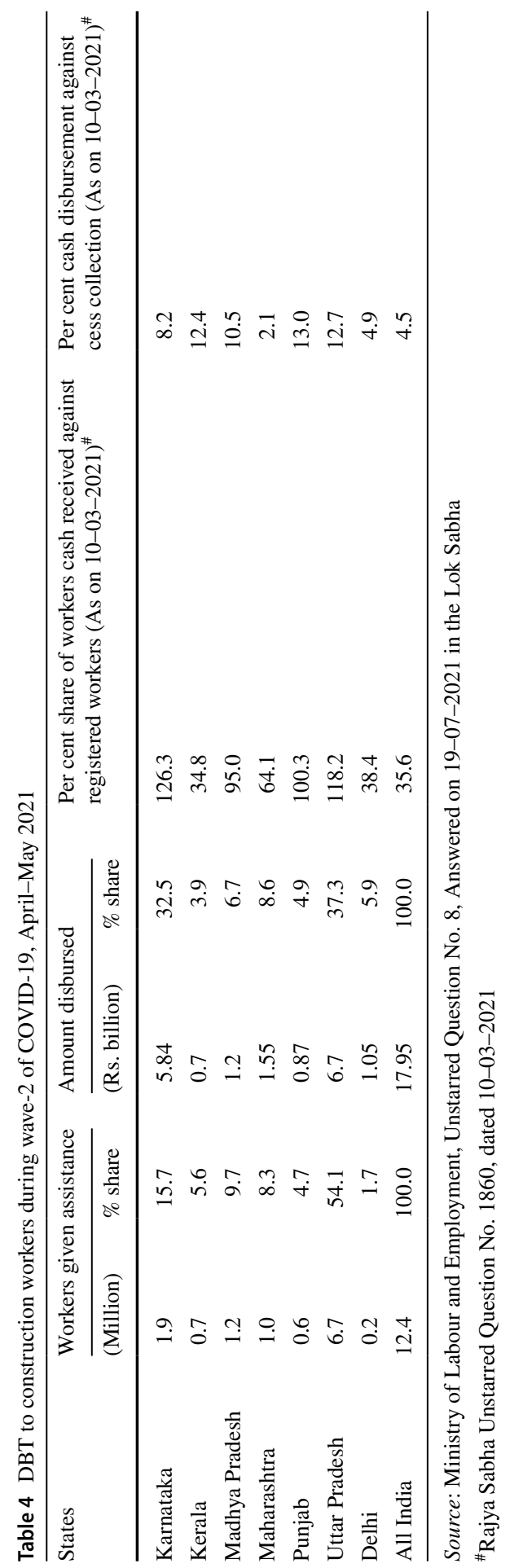


Mode Project (2020) of MoLE have mentioned that the domicile status of a worker should not prevent the worker from registration and that only Aadhar and bank details are necessary, whether the advice has been taken seriously and implemented by states and CWBs is doubtful.

Apart from the direct cash benefit to informal construction workers, MoLE also announced that it will provide $24 \%$ of wages as Employment Provident Fund benefit to all workers earning less than Rs. 15,000 per month and working in any establishment employing not more than 100 workers (Jha, 2020). But the scheme at large does not appear to be helpful for construction workers due to the high informality and almost complete absence of social protection. The estimation from PLFS 2018-2019 data shows that not more than one per cent of construction workers could benefit under this scheme.

\section{Existing Issues and Challenges}

Some basic issues of registration of workers and timely renewal and the collection and utilisation of cess still exist. The state-wise analysis of registration of workers, collection and utilisation of cess, and implementation of welfare schemes shows poor implementation of these measures even after 25 years of enactment of BOCW Act $1996^{4}$ (Soundararajan, 2013; and Jha, 2020). Table 5 shows that during the first wave of COVID-19, out of 54 million construction workers in 2018-2019, only 35 million workers were registered (as in 2019). Further, it can be noticed that the ratio of accounts seeded with Aadhar vis-à-vis registered is only $51.6 \%$.

The issue of registration got highlighted during the first wave of COVID-19. Although the registration of workers has increased by $21 \%$ between 2011 and 2019 and overall $64 \%$ workers are registered with $\mathrm{CWBs}$, there is still a huge variation in the rate of registration across states. States like Assam, Bihar, Chhattisgarh, Jharkhand, Odisha, Punjab, and Rajasthan have shown more than $50 \%$ compound growth in registration between 2011 and 2019. But, the total registration of workers was $30 \%$ and below in Jharkhand, Assam, and Bihar. Kerala (-1.3\%) and Tamil Nadu $(3.7 \%)$ registered the lowest growth in the last 8 years. A more important issue, however, is related to the annual renewal of registered workers and linking of the bank accounts of registered workers to Aadhar, so that welfare measures could be availed. Information in Table 5 shows that around 9 million workers in 2020 were not able to renew their registration.

The renewal of registration was relatively low in states like Delhi (7.3\%), Madhya Pradesh (28.9\%), Punjab (34.8\%), and Uttar Pradesh (39.5\%). Even states like Bihar, Chhattisgarh, Gujarat, Jharkhand, Kerala, Karnataka, and Maharashtra where live registration rate was higher, had low seeding of Aadhar with the bank account. The related issue is faulty registration process as pointed out in the social audit of BOCW Act in Delhi and Rajasthan sponsored by MoLE on the direction of the

\footnotetext{
4 As the BOCW Act has been subsumed into Social Security Code 2020, the provisions of the act would depend on the enforcement of the code and its effective implementation.
} 


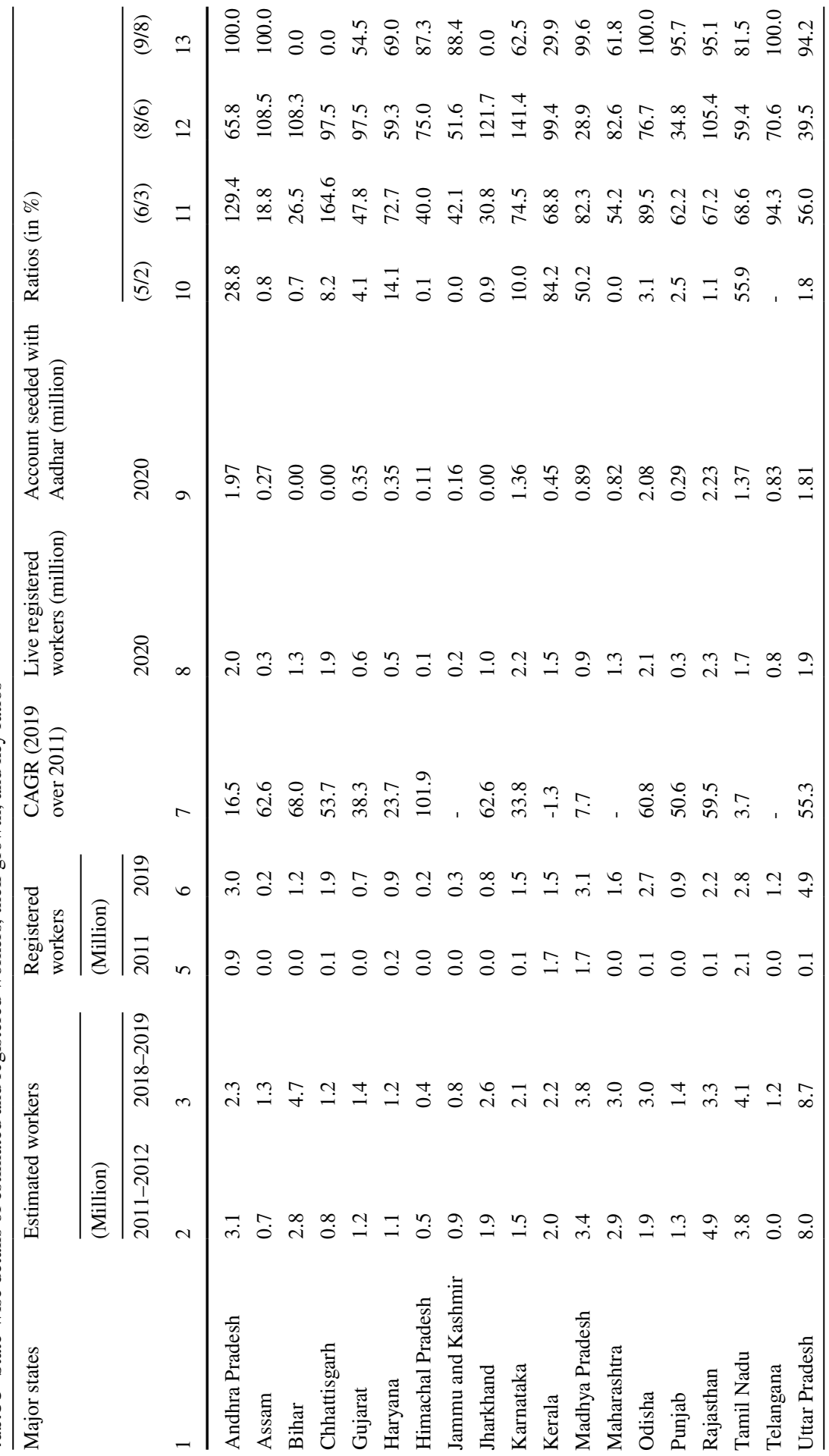




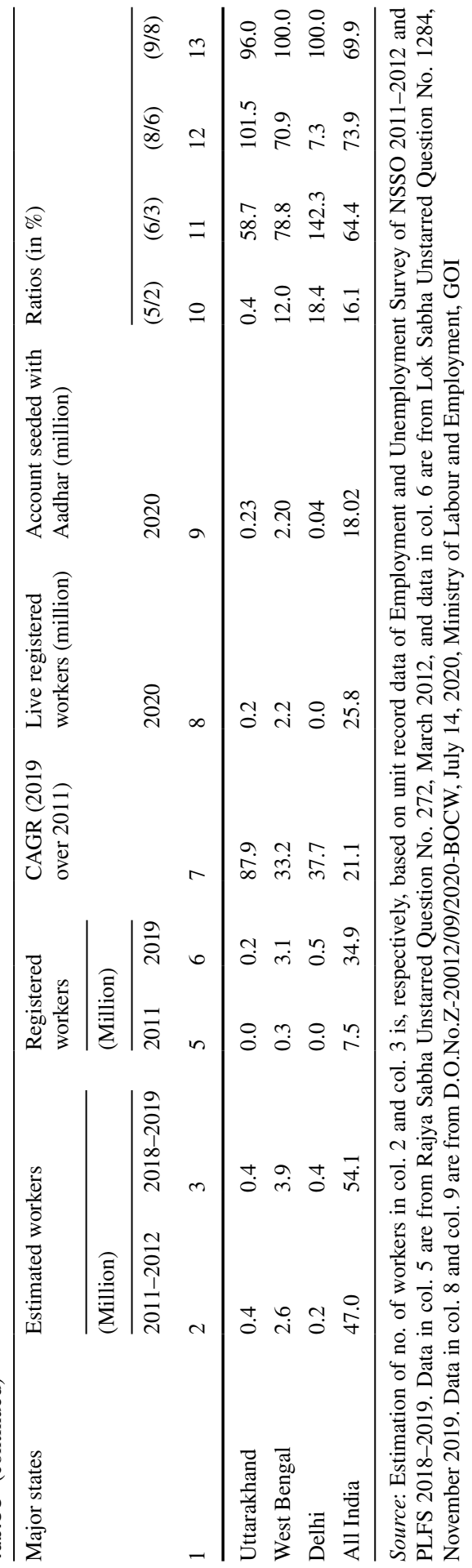


Supreme Court (MoLE, 2018a, 2020). In Delhi, organisations responsible for the social audit found instances of selective registration, non-updation of identity cards, and enrolment of non-construction workers as beneficiaries. The social audit report conducted by Aajeevika Bureau in Salumbar block of Udaipur district in Rajasthan in 2018 found that out of 1474 individuals, 39\% workers were not engaged in construction activities. As noticed in the case study analysis, the prevalence of the same may have risen during COVID-19. In a case study of workers, it is found that many workers managed to get themselves registered with CWB in Delhi while doing some other kind of casual work. This issue is highlighted in the narrative of one of the respondents:

Thirty-five year old Mamta Devi, a native of Madhubani district of Bihar, lives in a notified slum in Rangpuri of South-West district in Delhi. She is a domestic worker in a society located in Vasant Kunj area in Delhi. While enquiring about COVID-19 related effects on her health and income and if any kind of relief has been received by the government, she informed having received Rs. 5000 in her bank account during the first wave of COVID-19. When asked about the specific type and mode of assistance, she revealed that she has a labour card issued by the Delhi Building and Other Construction Welfare Board. She managed to get this card last year through her relatives from a labour camp near Tihar jail in Hari Nagar. She did not get the benefit during second wave as her labour card was not renewed. According to her, there are many such workers in the slum who have labour cards but are doing domestic and other kinds of non-construction jobs (Primary Survey by Author, Rangpuri Slum, Mahipalpur, Delhi, June 16, 2021).

Cess collection and its optimum utilisation is another point of discussion. In this regard, several directions have been given by the Parliamentary Standing Committee on Labour and by the Supreme Court to strengthen the mechanism of cess collection and its proper utilisation for the welfare of workers (Jha, 2020). Some progress in terms of spending has been observed, but still utilisation ratio is very low (Table 6). The MoLE has also recognised that welfare cess levied and collected to promote welfare and social security is underutilised (MoLE, 2020). At the aggregate level, utilisation ratio of cess has significantly increased in the last 8 years, but still over $60 \%$ of cess collected is found to be unutilised in 2019. Between 2019 and 2020, around Rs. 113.7 billion cess was collected, but only Rs. 27.8 billion was spent. Even during the first wave of COVID-19, only $11 \%$ cess was used in DBT to construction workers.

As observed in Table 6, there is large-scale spatial variation in the collection and utilisation of cess. More than $50 \%$ of the total cess in 2019 was collected by six states only. This includes Maharashtra, Karnataka, Uttar Pradesh, Tamil Nadu, Madhya Pradesh, and Haryana. However, a few of these states fall short of the targeted amount. Collection of cess fund in general is found proportional to the share of construction GVA to national GVA (Fig. 4), but states like Tamil Nadu and Uttar Pradesh that are ranked high in construction GVA contribution have relatively less cess collection. Maharashtra on the other hand with the third highest construction GVA of $9.5 \%$ in 2019 collected $14.9 \%$ cess. Similar variation can also be observed 
Table 6 Key ratios of cess spent and collected and share of construction GVA

\begin{tabular}{|c|c|c|c|c|c|c|}
\hline \multirow[t]{2}{*}{ Major states } & \multicolumn{2}{|c|}{$\begin{array}{l}\text { Ratio of } \\
\text { amount of } \\
\text { cess spent } \\
\text { and amount } \\
\text { of cess col- } \\
\text { lected }(\%)\end{array}$} & \multicolumn{2}{|c|}{$\begin{array}{l}\text { Percentage of } \\
\text { cess collec- } \\
\text { tion }\end{array}$} & \multicolumn{2}{|c|}{$\begin{array}{l}\% \text { share of } \\
\text { construc- } \\
\text { tion GVA } \\
\text { to national } \\
\text { GVA }\end{array}$} \\
\hline & 2011 & 2019 & 2011 & 2019 & 2011 & 2019 \\
\hline 1 & 4 & 5 & 2 & 3 & 6 & 7 \\
\hline Andhra Pradesh & 2.7 & 21.9 & 10.9 & 4.8 & 4.8 & 4.6 \\
\hline Assam & 0.1 & 21.6 & 0.4 & 1.8 & 1.5 & 2.3 \\
\hline Bihar & 0.1 & 14.3 & 2.3 & 3.2 & 3.5 & 3.8 \\
\hline Chhattisgarh & 12.1 & 83.7 & 0.6 & 2.3 & 2.4 & 2.4 \\
\hline Gujarat & 0.1 & 9.4 & 4.2 & 4.2 & 5.7 & 5.7 \\
\hline Haryana & 1.6 & 24.6 & 7.6 & 5.0 & 3.8 & 3.8 \\
\hline Himachal Pradesh & 0.0 & 13.9 & 1.2 & 1.4 & 0.8 & 0.9 \\
\hline Jammu and Kashmir & - & 42.4 & 0.0 & 1.4 & 0.8 & 0.9 \\
\hline Jharkhand & 0.6 & 53.2 & 0.4 & 0.9 & 1.9 & 1.8 \\
\hline Karnataka & 0.8 & 89.1 & 14.9 & 10.2 & 6.5 & 6.2 \\
\hline Kerala & 76.6 & 120.5 & 10.6 & 3.9 & 6.8 & 7.0 \\
\hline Madhya Pradesh & 36.5 & 53.8 & 9.8 & 5.4 & 4.5 & 4.7 \\
\hline Maharashtra & 0.0 & 5.4 & 0.2 & 14.9 & 10.4 & 9.5 \\
\hline Odisha & 0.0 & 77.5 & 1.8 & 3.7 & 2.6 & 2.6 \\
\hline Punjab & 1.5 & 53.7 & 2.5 & 2.7 & 2.5 & 2.4 \\
\hline Rajasthan & 0.0 & 55.7 & 0.6 & 4.5 & 5.6 & 5.0 \\
\hline Tamil Nadu & 43.6 & 26.6 & 8.7 & 6.0 & 11.9 & 13.1 \\
\hline Telangana & - & 21.7 & 0.0 & 2.4 & 2.9 & 2.8 \\
\hline Uttar Pradesh & 0.0 & 27.1 & 1.3 & 9.6 & 10.9 & 11.7 \\
\hline Uttarakhand & 0.0 & 27.2 & 0.1 & 0.5 & 1.1 & 1.3 \\
\hline West Bengal & 0.9 & 44.7 & 5.1 & 4.3 & 5.7 & 6.6 \\
\hline Delhi & 4.3 & 9.4 & 15.2 & 4.4 & 2.1 & 2.5 \\
\hline All India & 17.1 & 39.0 & 100.0 & 100.0 & 100.0 & 100.0 \\
\hline
\end{tabular}

Source: Data relating to cess collected and spent for 2019 have been compiled from Lok Sabha Unstarred Question No-278 (as on 31-03-2019). Information on State GVA at 2011-2012 price (as on 15-03-2021) has been compiled from National Account Statistics, MOSPI

in utilisation ratios. Some of the important states like Gujarat, Maharashtra, and Delhi spent less than $10 \%$ of cess in 2019, whereas Kerala, Karnataka, and Chhattisgarh reported more than $80 \%$ spending of cess.

From the analysis, it is observed that utilisation of cess and registration of workers is not proportionally related. Even in those states where normal and active registration rates are high, spending of cess is very low. To illustrate, Gujarat and Maharashtra with more than $80 \%$ active registration spent less than $10 \%$ of cess available in 2019. The data on registration are contested with respect to Chhattisgarh which 


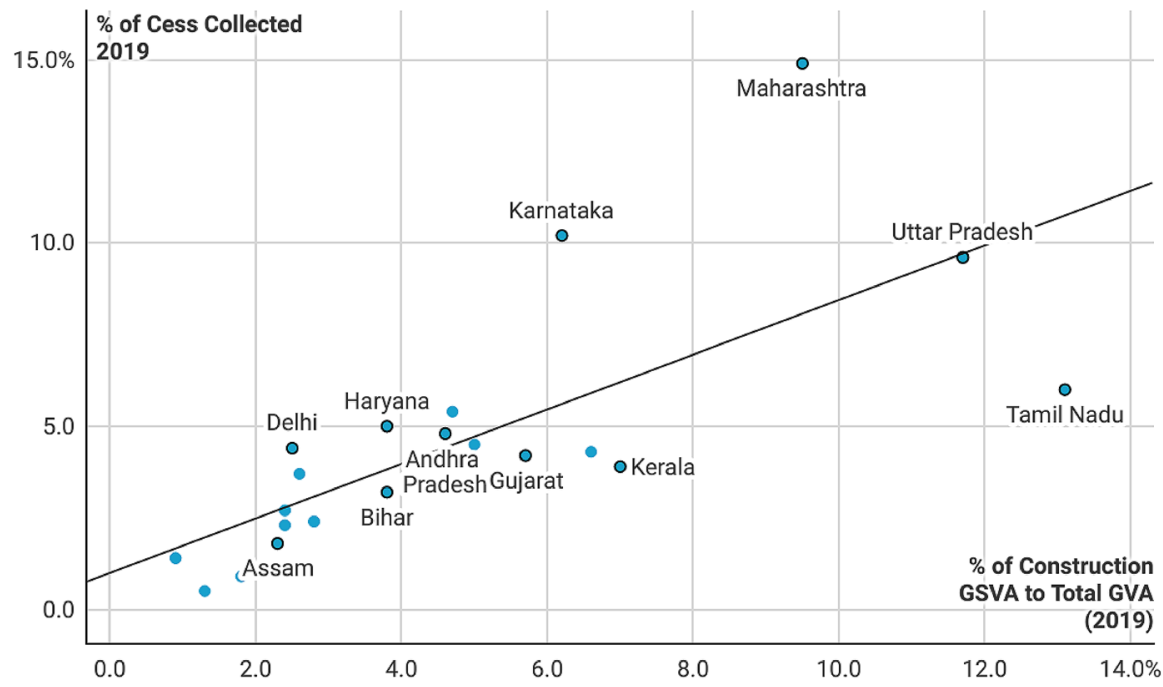

Fig. 4 Cess collection and share of construction GVA. Source: Data relating to cess collected and spent for 2019 have been compiled from Lok Sabha Unstarred Question No. 278, 2019, and information on State GVA at 2011-2012 price (as on 15-03-2021) has been taken from National Account Statistics, MOSPI

shows very high active registration and utilisation ratio, but the state has no account seeded with Aadhar (see Table 5). In Kerala, also only 29\% bank accounts are linked to Aadhar Card, but state CWB claims to have spent more than $100 \%$ cess in 2019.

The lack of uniformity in the design and implementation of welfare measures has been a major concern, and it has got more attention during COVID-19. According to Model Welfare Framework and Mission Mode Project, health, pension, skill development, and education should be given priority. It is also advised to CWBs to enrol construction workers in central and state government social welfare schemes. But the reality is that still a majority of the state construction welfare boards are running a large number of welfare schemes which are not necessarily required to be covered through the cess fund.

These issues can be addressed if the CWBs work effectively and implement the welfare measures as per the guidelines of the MoLE and the mandate of BOCW Act 1996. The Supreme Court in its judgement in 2018 had already given detailed directions related to registration of workers, ${ }^{5}$ strengthening the mechanism of cess collection, develops a composite model framework scheme in a specified time span to do away with the multiplicity of schemes, and to conduct social audit reports on the implementation of BOCW Act. Following the direction of the Supreme Court, MoLE formulated a Model Welfare Framework and Action Plan in 2018. The

\footnotetext{
5 The Supreme Court in its judgement on June 21, 2021, has invoked that registration of all informal workers including the construction workers is pivotal and most important to get the social security benefits.
} 
salience of the action plan was related to time bound implementation of actions, and modification and simplification of the BOCW Rules 1998. It was suggested that each registered worker will be given a unique identity card that will help in portability of welfare schemes. Workers can self-certify the number of days worked in the past year. Similarly for cess collection, all private and public organisations (such as Railways) were asked to pay cess at the stipulated rate and to transfer the same to CWBs within 30 days of its collection. The Model Welfare Framework also prioritises life and disability care, health and education, and housing and skill development over all other existing benefits. It is only after meeting these priority expenses that any balance of fund may be used for providing additional benefits.

But during COVID-19, it came to notice that only 18 million workers (34\% of total estimated workers) could avail the cash assistance through DBT due to nonavailability of Aadhar and bank account details in the first wave. States like Bihar where details of bank account and Aadhar are mandatory to fill at the time of registration show that no account is seeded with Aadhar. Overall, the registration rate has increased, but $30 \%$ workers are still not registered and there is a big issue of faulty registration. With continued emphasis on registration, MoLE once again launched a Mission Mode Project (MMP) on July 6, 2020, to register all the left-out construction workers. The project also aimed at providing social security to all, subsistence wage allowance, and collected construction welfare data in a time bound manner. The outcomes of the project, however, are not yet known. The latest information given by MoLE in Rajya Sabha in March 2021 shows that only 34.7 million construction workers are registered with welfare boards (Rajya Sabha, 2021b, 2020b).

Infection prevention and maintenance of health and hygiene are some of the challenges that also need attention. Minimising the spread of virus should be a top priority given the nature of workforce, living, and working conditions in the construction sector. In construction, majority of the work is performed on site, and hence, maintaining physical distance is quite difficult. Majority of the workers are also less educated and minimally protected. Living and working conditions are already poor; therefore, maintaining hygiene at worksite and at living place is very important. Past studies (Srivastava and Jha, 2016; Jha, 2017) show that living conditions of workers are already a major challenge. The housing accommodations for the workers at the large construction sites are generally very poor, and most of the workers live in jhuggi-jhopri (temporary sheds) where per worker availability of space in a room is less than 50 square feet. Access to toilets and drinking water is also poor. Although ILO (2020c) has already issued detailed guidelines for the construction sector to maintain health and hygiene, it would depend on how employers can effectively implement these guidelines. Labour unions as an important stakeholder can play a crucial role in ensuring that workers get a healthy workplace environment. At a large worksite, a flexible model of work can be adopted, the living place can be cleaned and sanitised regularly, and workers can be given some extra premium to maintain their hygiene and stay healthy. BOCW Rules 1998 (Rule 39 and 223) provide detailed guidelines on health and safety policy and medical examination of workers on a periodic basis which, if followed, can address problems emerging due to COVID-19. This coupled with vaccination can bring the lives and livelihoods of construction workers back on track. Government both at the centre and the states can 
play a crucial in providing speedy access to vaccination, and employers and workers' organisation can create awareness among workers to get vaccinated. Although the active cases in India have declined to $1.22 \%$ as on September 3, 2021, and a total of 67 billion people have received at least one dose vaccination, still a large segment of the population remains to be covered (MoHFW, 2021).

\section{Conclusion}

Construction has been the worst hit sector because of its sensitive nature and large presence of informal and circular migrant workers. Cash assistance through DBT has partly helped in reducing the misery of the construction workers, but not more than $35 \%$ of the total workers in 2018-2019 received the benefit provided by CWBs. A significant proportion did not get benefits due to non-renewal of their annual registration and non-linking of Aadhar to the bank account. In terms of total amount disbursed, huge variation is noticed across the states; in fact, few states are found to have not provided any cash benefit. The other concern is how many migrant workers are benefitted in total. The benefits to migrant workers appear less than hoped because in many states in the absence of a domicile certificate they are not eligible to register with the CWBs.

During this crisis, it has been realised that registration of all informal workers through a unified system is vital to bring some kind of formality in the labour market and also to provide direct welfare measures. According to the Supreme Court judgment dated June 21, 2021, registration is pivotal and most important insofar as welfare measures are concerned. It was directed by the court that both union and state governments should complete the process of registration of all informal workers and create a database latest by December 31, 2021. Before that, in 2018 the Supreme Court had given specific direction to MoLE to scale up and simplify the process of registration of construction workers in a time bound manner. In response to the direction, MoLE made a Model Welfare Framework in 2018 through which all CWBs were advised to speed the process of registration, simplify the process, and create an online mechanism of registration. Again in 2020, MoLE started a Mission Mode Project to increase the coverage of registration and create a dynamic database of construction workers. The outcome of the project is not exactly known, but in some states the process of online registration has begun. For example, an e-Nirman portal was launched by Gujarat government on June 8, 2021, for online registration of construction workers. In some states (Uttar Pradesh and Andhra Pradesh, for instance), the process of online registration began just after the implementation of Model Welfare Framework in 2018. More recently on the direction of the Supreme Court, MoLE has launched the e-Shram portal for registration of all kinds of informal workers. Additionally, e-Shram portal will allow portability of social security and welfare benefits to the migrant and construction workers.

But the eligibility criteria for registration of workers on e-Shram portal are different from the criteria of registration of a construction worker under section-12 of the BOCW Act 1996. The question is: How to achieve parity? Even section-106 of the Social Security Code 2020 lays down the same criteria as stated in the BOCW Act 
1996. There is a need to bring uniformity in the registration of construction workers in any of these platforms. More importantly, multiple platforms for registration may create confusion among workers. It would be better if registration of construction workers is done through CWBs by speeding up the process and simplifying the norms.

Portability of registration and welfare schemes is a major concern for migrant construction workers, and the ways to deal with it have already been discussed in the Mission Mode Project. However, the main concern is how to ensure registration of migrant construction workers in destination states. Moreover, with the start of e-Shram portal the question now is whether the construction workers registered with this portal would get all benefits provided by CWBs.

Lack of uniformity in design and implementation of social welfare measures by the CWBs is also an issue that needs to be resolved. Now, a new task would be to synchronise centrally sponsored welfare schemes implemented through the e-Shram portal with state-specific welfare schemes implemented through state CWBs. In its absence, there will be a duplication of welfare measures by the union government and the state governments.

As the pandemic is not yet over, the efforts to vaccinate, create awareness, provide extra premium to workers, and to maintain health and hygiene at worksite and living place are very crucial. For this purpose, it is very important for all stakeholders to take collective action.

Funding The study has not received any grant from any institution/agency. It is solely self-financed.

\section{Declarations}

Conflict of interest There is no conflict of interest involved.

\section{References}

APU. 2021. State of Working India 2021: One Year of COVID-19. Centre for Sustainable Employment, Azim Premji University.

Bhattacharya, Shrayana, and Sutirtha Sinha Roy. 2021. Intent to Implementation: Tracking India's Social Protection Response to COVID-19, Discussion Paper No. 2107. World Bank.

Breman, Jan. 2020. The Pandemic in India and Its Impact on Footloose Labour. The Indian Journal of Labour Economics 63 (4): 901-919.

Buckley, Michelle et al. 2016. Migrant Work and Employment in the Construction Sector. International Labour Organisation.

Dalberg. 2020. Efficacy of government entitlements for low-income families during Covid-19. https:// impactsofcovid.in/assets/front_assets/download/20.07.27_Efficacy\%20of\%20government\%20ent itlements\%20for\%20low-income\%20families\%20during\%20Covid-19.pdf

Desai, Renu. 2017. Entitlements of Seasonal Migrant Construction Workers to Housing, Basic Services and Social Infrastructure in Gujarat's Cities: A Background Policy Paper. Working Paper 35, Centre for Urban Equity, CEPT University, Ahmedabad.

GOI. 2021. Economic Survey 2020-2021, Vol II, Ministry of Finance, Government of India.

Government of Bihar. 2021. Budget Speech 2021-2022. https://openbudgetsindia.org/dataset/5c943f0f7895-4764-b125-b1842a1e4678/resource/dbc0e51d-d2bb-4560-8c0b-618e4133020b/download/ budget-speech.pdf 
Hindustan Times. 2021. Over 1.3 million Migrants Left Delhi During 2nd Wave of COVID-19, July 2. https://www.hindustantimes.com/cities/delhi-news/over-1-3-million-migrants-left-city-during-2ndwave-shows-data-101625173931020.html

ILO. 2020a. COVID-19 and the World of Work: Impact and Policy Responses. ILO Monitor, 1st ed. Geneva: International Labour Organisation.

ILO. 2020b. ILO Monitor: COVID-19 and the World of Work, 2nd ed. Geneva: International Labour Organisation.

ILO. 2020c. COVID-19 Action Checklist for the Construction Industry: Practical Measures to help Employers, Workers and the Self-Employed Prevent and Mitigate the Transmission of COVID-19 in Construction Work. Geneva: International Labour Organisation. https://www.ilo.org/global/topics/ safety-and-health-at-work/resources-library/publications/WCMS_764847/lang--en/index.htm

ILO. 2021a. COVID-19 and the World of Work: Impact and Policy Responses. ILO Monitor, 7th ed. Geneva: International Labour Organisation.

ILO. 2021b. Impact of COVID-19 on the Construction Sector. ILO Sectoral Brief. ILO, Geneva: International Labour Organization.

Jha, Ajit. 2020. COVID-19 Relief Package: Will Central Largesse Help Construction Workers. Economic and Political Weekly 55 (17): 20-22.

Jha, Praveen, and Manish Kumar. 2020. Labour in India and the COVID-19 Pandemic. The Indian Economic Journal 68 (3): 417-437.

Jha, Ajit K. 2017. The Construction Industry in India: Production Conditions, Labour Practices and Skill Development. Ph.D. Thesis. Jawaharlal Nehru University.

Kapoor, Radhicka. 2020. TIF: The Unequal Effects of the COVID-19 Crisis on the Labour Market. The India Forum. https://www.theindiaforum.in/article/unequal-effects-covid-19-crisis-labour-market

Kesar, Surbhi et al. 2020. Pandemic, Informality, and Vulnerability: Impact of COVID-19 on Livelihoods in India, CSE Working Paper 2020-01, Azim Premji University.

Lingard, Helen, et al. 2021. Special issue: What have we learnt from the COVID-19 global pandemic: Improving the construction industry's abilities to foresee, respond to and recover from future endemic catastrophes. Construction Management and Economics 39 (2): 192-197.

Mehrotra, Santosh and Tuhinsubhra Giri. 2019. The Size Structure of India's Enterprises: Not Just the Middle is Missing, CSE Working Paper 25. Azim Premji University.

MoHFW. 2021. COVID-19 India as on 2nd September 2021, 8:00 IST. Ministry of Health and Family Welfare. https://www.mohfw.gov.in/pdf/CummulativeCovidVaccinationReport02september2021. pdf.

MoLE. 2020. D.O.No.Z-20012/09/2020-BOCW dated July 14, 2020, Ministry of Labour and Employment, Government of India. https://labour.gov.in/sites/default/files/DO.pdf

MoLE. 2018a. Model Welfare Scheme for Building and Other Construction Workers and Action Plan for Strengthening Implementation Machinery, Ministry of Labour and Employment, Government of India. https://labour.gov.in/whatsnew/model-welfare-scheme-building-and-other-construction-worke rs-and-action-plan-strengthening

MoLE. 2018b. Report Pilot Social Audit of BOCW Act in Delhi, Ministry of Labour and Employment, Government of India. http://www.nirmana.org/Documents/social_audit_report-delhi.pdf

PIB. 2020a. Finance Minister announces Rs 1.70 Lakh Crore Relief Package under Pradhan Mantri Garib Kalyan Yojana for the Poor to Help them Fight the Battle Against Corona Virus, Ministry of Finance, Press Information Bureau, Press Release, March 26. https://www.pib.gov.in/PressRelea sePage.aspx?PRID=1608345

PIB. 2020b. Labour Ministry Issues Advisory to All States/UTs to use Cess Fund for Welfare of Construction Workers, Ministry of Labour and Employment, Press Information Bureau, Press Release, March 24. https://pib.gov.in/PressReleasePage.aspx?PRID=1607911

PIB. 2020c. Pradhan Mantri Garib Kalyan Package: Progress so Far, Ministry of Finance, Press Information Bureau, Press Release, April 23. https://pib.gov.in/PressReleseDetail.aspx?PRID=1617393

PIB. 2020d. Prime Minister Garib Kalyan Package: Progress so Far, Ministry of Finance, Press Information Bureau, Press Release, June 20. https://pib.gov.in/PressReleasePage.aspx?PRID=1632863

PIB. 2020e. Pradhan Mantri Garib Kalyan Package: Progress so Far, Ministry of Finance, Press Information Bureau, Press Release, September 8. https://pib.gov.in/Pressreleaseshare.aspx?PRID=1652231

PIB. 2021. Provisional Estimates of Annual National Income, 2020-2021 and Quarterly Estimates (Q4) Of Gross Domestic Product, 2020-2021, Ministry of Statistics and Programme Implementation, Press Information Bureau, Press Release, May 31. https://pib.gov.in/PressReleasePage.aspx?PRID= 1723153 
Rajan, S., P. Sivakumar. Irudaya, and Aditya Srinivasan. 2020. The COVID-19 Pandemic and Internal Labour Migration in India: A Crisis of Mobility. The Indian Journal of Labour Economics 63 (4): 1021-1039.

Roy, Shamindra Nath, Manish, and Mukta Naik. 2017. Migrants in Construction Work: Evaluating their Welfare Framework. Policy Brief. Centre for Policy Research, New Delhi.

Lok Sabha. 2020. Unstarred Question No. 1253 To Be Answered On 19.09.2020 Welfare of Unskilled and Skilled Migrant Labourers. Ministry of Labour and Employment.

Lok Sabha. 2021a. Unstarred Question No. 8 To Be Answered On 19.07.2021 Building and Other Construction Workers, Ministry of Labour and Employment.

Rajya Sabha. 2021b. Unstarred Question No. 1860 To Be Answered On 10.03.2021 Construction Workers Registered Under BOCW Act, 1996. Ministry of Labour and Employment. https://pqars.nic.in/ annex/253/AU1860.pdf

Soundararajan, Vidhya. 2013. Construction Workers: Amending the Law for More Safety. Economic and Political Weekly 48 (23): 21-25.

Srivastava, Ravi. 2018. Building India Brick by Brick: Labourers in the Construction Industry. In India Exclusion Report, 2017-2018. New Delhi: Yoda Press.

Srivastava, Ravi, and Ajit Jha. 2016. Capital and Labour Standards in the Organised Construction Industry in India: A Study Based on Fieldwork in the National Capital Region of Delhi. Project Report 02, Centre for the Study in Regional Development: JNU, New Delhi.

Srivastava, R. 2020a. Understanding Circular Migration in India. Its Nature and Dimensions, the Crisis under Lockdown and the Response of the State. IHD Centre for Employment Studies Working Paper 04/2020, Institute for Human Development, New Delhi.

Srivastava, Ravi. 2020b. Labour Migration, Vulnerability, and Development Policy: The Pandemic as Inflexion Point. The Indian Journal of Labour Economics 63 (4): 859-883.

Srivastava, Ravi et al. 2020c. Internal Migration in India and the Impact of Uneven Development and Demographic Transition across States: A study for evidence-based policy. New Delhi: Institute for Human Development.

SWAN. 2020. 32 Days and Counting: COVID-19 Lockdown, Migrant Workers, and the Inadequacy of Welfare Measures in India. strandedworkers.in/mdocs-posts/32-days-and-counting/

The Hindu. 2021. Parliamentary Panel Recommends Money in banks, social security measures for informal workers, August 3. https://www.thehindu.com/news/national/parliamentary-panel-recommendsmoney-in-banks-social-security-measures-for-informal-workers/article35703931.ece

The Supreme Court of India. 2018. WRIT PETITION (CIVIL) NO. 318 OF 2006. Order Passed on March 19, 2018. https://indiankanoon.org/doc/71520761/

The Supreme Court of India. 2021. SUO MOTU WRIT PETITION (CIVIL) NO.6 OF 2020 PROBLEMS AND MISERIES OF MIGRANT LABOURERS. Order Passed on June 29, 2021. https://main.sci. gov.in/supremecourt/2020/11706/11706_2020_36_1501_28166_Judgement_29-Jun-2021.pdf

van der Loop, Theo. 1996. Industrial Dynamics and Fragmented Labour Market: Construction Firms and Labourers in India. New Delhi: Sage Publication.

Walter, Dagmar. 2020. Implications of COVID-19 for Labour and Employment in India'. The Indian Journal of Labour Economics 63 (1): 547-551.

Wells, Jill. 2007. Informality in the construction Sector in Developing Countries'. Construction Management and Economics 25 (1): 87-93.

Publisher's Note Springer Nature remains neutral with regard to jurisdictional claims in published maps and institutional affiliations. 